\title{
Keratinases Produced by Aspergillus stelliformis, Aspergillus sydowii, and Fusarium brachygibbosum Isolated from Human Hair: Yield and Activity
}

\author{
Suaad S. Alwakeel ${ }^{1}$, Fuad Ameen ${ }^{2, *}$ (D) Hussah Al Gwaiz ${ }^{1}$, Hana Sonbol ${ }^{1}$, Salma Alghamdi ${ }^{1}$, \\ Ahmad M. Moharram ${ }^{3}$ and Osama A. Al-Bedak ${ }^{4}$ \\ 1 Department of Biology, College of Science, Princess Nourah bint Abdulrahman University, \\ Riyadh 11671, Saudi Arabia; ssalwakeel@pnu.edu.sa (S.S.A.); hialgwaiz@pnu.edu.sa (H.A.G.); \\ HSSonbol@pnu.edu.sa (H.S.); saAtAlghamdi@pnu.edu.sa (S.A.) \\ 2 Department of Botany \& Microbiology, College of Science, King Saud University, Riyadh 11451, Saudi Arabia \\ 3 Department of Botany and Microbiology, Faculty of Science, Assiut University, Assiut 71511, Egypt; \\ ahmed.marzouk@science.au.edu.eg \\ 4 Assiut University Mycological Centre (AUMC), Assiut University, Assiut 71511, Egypt; \\ osamaalbedak@gmail.com \\ * Correspondence: fuadameen@ksu.edu.sa
}

\section{check for}

updates

Citation: Alwakeel, S.S.; Ameen, F.; Al Gwaiz, H.; Sonbol, H.; Alghamdi, S.; Moharram, A.M.; Al-Bedak, O.A. Keratinases Produced by Aspergillus stelliformis, Aspergillus sydowii, and Fusarium brachygibbosum Isolated from Human Hair: Yield and Activity. J. Fungi 2021, 7, 471. https:// doi.org/10.3390/jof7060471

Academic Editors: Thomas Edison E. dela Cruz and Fahrul Huyop

Received: 14 April 2021

Accepted: 7 June 2021

Published: 10 June 2021

Publisher's Note: MDPI stays neutra with regard to jurisdictional claims in published maps and institutional affiliations.

Copyright: (c) 2021 by the authors. Licensee MDPI, Basel, Switzerland. This article is an open access article distributed under the terms and conditions of the Creative Commons Attribution (CC BY) license (https:// creativecommons.org/licenses/by/ $4.0 /)$.

\begin{abstract}
Twenty fungal strains belonging to 17 species and isolated from male scalp hair were tested for their capacity to hydrolyze keratinous material from chicken feather. The identification of the three most efficient species was confirmed by sequencing of the internal transcribed spacer (ITS) region of rDNA. Activities of fungal keratinases produced by Aspergillus stelliformis (strain AUMC 10920), A. sydowii (AUMC 10935), and Fusarium brachygibbosum (AUMC 10937) were 113, 120, and $130 \mathrm{IU} \mathrm{mg} \mathrm{mg}^{-1}$ enzymes, respectively. The most favorable conditions were at $\mathrm{pH} 8.0$ and $50{ }^{\circ} \mathrm{C}$. Keratinase activity was markedly inhibited by EDTA and metal ions $\mathrm{Ca}^{+2}, \mathrm{Co}^{+2}, \mathrm{Ni}^{+2}, \mathrm{Cu}^{+2}, \mathrm{Fe}^{+2}$, $\mathrm{Mg}^{+2}$, and $\mathrm{Zn}^{+2}$, with differences between the fungal species. To the best of our knowledge, this is the first study on the activity of keratinase produced by A. stelliformis, A. sydowii, and F. brachygibbosum. F. brachygibbosum keratinase was the most active, but the species is not recommended because of its known phytopathogenicty. Aspergillus sydowii has many known biotechnological solutions and here we add another application of the species, as producer of keratinases. We introduce A. stelliformis as new producer of active fungal keratinases for biotechnological solutions, such as in the management of keratinous waste in poultry industry.
\end{abstract}

Keywords: keratin; microbial keratinases; feather; waste management; enzymes; biotechnology

\section{Introduction}

Keratins are structural elements of wool, hooves, horns, hair, nails, and feathers. Forty million tons of keratinous waste is generated in the USA, Brazil, and China per year [1]. The meat industry-in slaughterhouses-generates millions of tons of keratinous waste in the world annually [2]. Chicken feathers alone are generated, up to two million tons [3]. In addition, the fur industry and barbershops generate keratinous waste. Only a small part of waste, mostly from slaughterhouses, is utilized as animal feed. Keratins are insoluble fibrillar proteins of the exterior defensive surfaces of vertebrates. Keratinous materials are known for their high stability owing to the firm stabilization of their polypeptide chains and the many disulfide bonds that cross these chains [4]. Keratins are not degraded by common protein breaking enzymes, i.e., proteases, such as pepsin and papain. Managing keratinous waste needs a low-cost solution, especially in developing countries.

Keratinous substrates are known to be degraded by fungi and bacteria that produce extracellular keratinolytic enzymes, i.e., keratinases [5-7]. Keratinophilic fungi are commonly found from many habitats. They have been found in soils, from Antarctica to 
the tropics, as well as from agricultural soils [8]. Keratinases are usually extracellular inducible enzymes secreted by different fungal genera, such as Aspergillus, Chrysosporium, Trichophyton, and Microsporum [9-11]. They are protease enzymes with widespread use in various industries. For instance, keratinase powder, produced using the bacterium Bacillus licheniformis and the fungus Parengyodontium album, is sold commercially. Keratinases are used in pharmaceutical industries, such as in vaccine production and preparation of bioactive peptides and serums. They are useful in the treatment of calluses, keratinized skin, psoriasis, and acne [12]. Manufacturing of cosmetic products, such as anti-dandruff shampoos, nutritional lotions, and creams use keratinases. They are commonly used in feed formulas, nitrogen fertilizers, and the leather industry [5,13-15]. As a novel solution, they may be used to treat wastewater containing keratin waste [16].

Keratinolytic fungi include Acremonium, Aphanoascus, Aspergillus, Chrysosporium, Cladosporium, Doratomyces, Fusarium, Lichtheimia, Microsporum, Paecilomyces, Scopulariopsis, Trichoderma, and Trichophyton. Many of these fungi are pathogenic. The pathogenicity and virulence of some fungi are often due to the high capability of the fungal strains to degrade both hard and soft types of keratin [17]. However, industrially interesting fungi are the non-pathogenic fungi that do not cause infections. Therefore, more research for suitable microorganisms is needed. Keratinases are active within a broad range of temperatures $\left(40-70^{\circ} \mathrm{C}\right)$ and $\mathrm{pH}$ values $(6-11)$ [1,6,12,18-22]; thus, optimum conditions need to be studied for biotechnological solutions.

The aim of the study was to find suitable and effective fungal species able to degrade keratinous materials to be used in different biotechnological applications. We isolated fungi from human hair and, after a preliminary experiment, chose the best three species to measure the yield and the activity of keratinases the fungi produced.

\section{Materials and Methods}

\subsection{Keratin Powder Preparation}

Chicken feathers $(50 \mathrm{~g})$ collected from poultry farms located in the Assiut district, Egypt, were defatted with chloroform-methanol (1:1) in continuous agitation for $24 \mathrm{~h}$, then washed three times with distilled water, and dried in the air. For keratin extraction, the chicken feathers were immersed in $1000 \mathrm{~mL}$ of $0.5 \mathrm{M}$ sodium sulfide for $6 \mathrm{~h}$ with continuous agitation at ambient conditions. Soluble keratin was first centrifuged for $10 \mathrm{~min}$ at $10,000 \times g$ and then precipitated from the supernatant using $70 \%$ ammonium sulfate. The precipitate was washed four times with distilled water, dried at $40^{\circ} \mathrm{C}$, and used as chicken keratin powder in keratinase assay experiments.

\subsection{Preliminary Experiment/Submerged Fermentation}

Twenty fungal strains (17 species) previously [23] isolated from scalp hair samples of males in Riyadh city, Saudi Arabia, were used individually as three replicates. Fungi were preliminary identified morphologically and deposited in the Culture Collection of the Assiut University Mycological Centre (AUMC), with accession numbers in Table 1. Fungi were revived and tested for their purity and viability on Czapek's agar medium (HiMedia, Mumbai, India).

Sterilized sucrose-free Czapek's broth containing 5.0\% (weight/weight) chicken feathers as the sole source of carbon and $0.1 \%$ glucose was used as a fermentation medium. In a $250 \mathrm{~mL}$ Erlenmeyer flask, $50 \mathrm{~mL}$ of fermentation medium was inoculated with $1 \mathrm{~mL}$ of cell suspension of the tested fungi. Spore suspension $(1 \mathrm{~mL})$ containing $1.8 \times 10^{8}$ spore $\mathrm{mL}^{-1}$ from 7-day-old culture of each fungus was inoculated into their own fermentation flasks ( $100 \mathrm{~mL}$ broth) and incubated at $30{ }^{\circ} \mathrm{C}$ for 15 days under shaking at $150 \mathrm{rpm}$. Then, supernatants were obtained by centrifugation at $10,000 \times g$ for $10 \mathrm{~min}$, and cell-free supernatants were used as the raw microbial keratinase enzymes in the preliminary keratinase activity assay. 
Table 1. Activity of fungal keratinases (mean $\pm S D, n=3$ ). AUMC no. = Culture Collection of the Assiut University Mycological Centre accession numbers.

\begin{tabular}{ccc}
\hline Fungal Species & $\begin{array}{c}\text { AUMC } \\
\text { No. }\end{array}$ & $\begin{array}{c}\text { Relative Activity } \\
\text { IU m } \mathbf{~ L}^{-\mathbf{1}} \mathbf{~ m i n}^{-\mathbf{1}}\end{array}$ \\
\hline $\begin{array}{c}\text { Alternaria alternata (Fries) Keissler } \\
\text { Alternaria alternata (Fries) Keissler }\end{array}$ & $10926 \pm 42$ \\
Alternaria botrytis Woudenberg and Crous & 10932 & $1680 \pm 120$ \\
Alternaria botrytis Woudenberg and Crous & 10931 & $1211 \pm 98$ \\
Alternaria chlamydosporigena Woudenberg and Crous & 10936 & $1018 \pm 87$ \\
Aspergillus nidulans Winter & 10915 & $1398 \pm 154$ \\
Aspergillus niger van Tieghem & 10933 & $935 \pm 70$ \\
Aspergillus stelliformis F. Sklenar, Jurjević and Hubka & 10912 & $52 \pm 23$ \\
Aspergillus sydowii (Bainier and Sartory) Thom and Church & 10920 & $3336 \pm 169$ \\
Aspergillus ustus (Bainier) Thom and Church & 10935 & $3523 \pm 188$ \\
Aureobasidium pullulans (de Bary) Arnaud & 10934 & $2091 \pm 197$ \\
Chaetomium globosum Kunze & 10914 & $129 \pm 11$ \\
Fusarium brachygibbosum Padwick & 10941 & $1600 \pm 156$ \\
Nodulisporium sp. & 10940 & $570 \pm 85$ \\
Penicillium chrysogenum Thom & 10937 & $3554 \pm 189$ \\
Penicillium glabrum (Wehmer) Westling & 10916 & $270 \pm 20$ \\
Phoma herbarum Westend & 10913 & $589 \pm 11$ \\
Hurviaria tsudae (Tsuda \& Ueyama) Deng, Tan and Shivas & 10929 & $218 \pm 49$ \\
Pyrenophora dematioidea (Bubák \& Wróbl.) Rossman and K.D. & 10919 & $258 \pm 12$ \\
Pyrenophora dematioidea (Bubák \& Wróbl.) Rossman and K.D. & 10930 & $580 \pm 33$ \\
Hyde & 10938 & $512 \pm 15$ \\
\hline
\end{tabular}

\subsection{Keratinase Activity Assay}

The reaction mixture contained $1.0 \mathrm{~mL}$ of the cell-free supernatant $+0.01 \mathrm{~g}$ chicken keratin powder (prepared in $1 \mathrm{~mL}$ of $50 \mathrm{mmol}$ citrate buffer $\mathrm{pH}$ 5.0). The mixture was incubated in a water bath at $50{ }^{\circ} \mathrm{C}$ for $60 \mathrm{~min}$. The reaction was stopped by adding $2.0 \mathrm{~mL}$ $10 \%$ trichloroacetic acid (TCA). The resulting precipitate was separated by centrifugation at $10,000 \times g$ for $10 \mathrm{~min}$. Then, $0.2 \mathrm{~mL}$ of the supernatant was diluted to $1.0 \mathrm{~mL}$ with purified water, and $5.0 \mathrm{~mL}$ of alkaline cupper reagent (sodium carbonate, $40 \mathrm{~g}$; tartaric acid, $7.5 \mathrm{~g}$; copper sulfate, $4.5 \mathrm{~g}$ and distilled. water, $1000 \mathrm{~mL}$; final $\mathrm{pH} 9.9 \pm 0.5$ ) was added. Afterwards, $0.5 \mathrm{~mL}$ of the Folin-Ciocalteu reagent was added and the tubes were kept in the dark for $30 \mathrm{~min}$ to allow the blue color formation. Negative control was prepared by incubating the enzyme solution with $2 \mathrm{~mL}$ of $10 \%$ TCA without keratin. Absorbance was measured at $660 \mathrm{~nm}$ (UV-visible spectrophotometer; T80+; UK), using tyrosine as the standard. One unit of keratinolytic activity corresponds to the enzyme amount that releases $1 \mu \mathrm{mol}$ tyrosine $\mathrm{mL}^{-1} \mathrm{~min}^{-1}$ under standard test conditions [24], according to the L-tyrosine standard curve (Equations (1)-(3)) [24].

Concentration of L-tyrosine $=$ absorbance $/(0.0018 \times 1000) \mathrm{mg} / \mathrm{mL}(=\mathrm{g} / \mathrm{L})$

Keratinase activity $=($ concentration of L-tyrosine $) / 0.0001812 \mathrm{IU} / \mathrm{mL} / \mathrm{min}$

Keratinase activity can be also expressed as IU/g (= IU $/ \mathrm{mL} / \mathrm{min} \times 100)$.

Total protein content was measured with the method of [25], using bovine serum albumin (BSA) as the standard and the specific keratinase activity per mg protein was calculated.

\subsection{Molecular Identification of the Potent Strains}

The three most active strains in the preliminary experiment were identified by sequencing. For the DNA extraction, small pieces of fungal mycelia from 7-day-old cultures of Aspergillus strains (AUMC 10920 and AUMC 10935) grown on malt extract agar (MEA) and Fusarium strain (AUMC 10937) on potato dextrose agar (PDA) at $25{ }^{\circ} \mathrm{C}$ were trans- 
ferred individually to $2 \mathrm{~mL}$ Eppendorf tubes. DNA extraction was performed as described by Moubasher et al. [26]. The PCR reaction was carried out in SolGent company (South Korea) using the universal primers ITS1 (5TCC GTA GGT GAA CCT GCG G 3), and ITS4 (5TCC TCC GCT TAT TGA TAT GC 3), in the reaction mixture described by [27-29]. Sequences obtained from SolGent Company were compared to sequences from GenBank using MAFFT (version 6.861b) with the default options [30]. Alignment gaps and parsimony uninformative characters were chosen as described by Criscuolo and Gribaldo [31]. Maximum likelihood (ML) and maximum parsimony (MP) phylogenetic analyses were conducted using PhyML 3.0 [32]. The robustness of the most parsimonious trees was tested by 100 bootstrap replications [33]. The best optimal model of nucleotide replacement for ML analyses was calculated using Smart Model Selection (SMS) version 1.8.1 [34]. The phylogenetic tree was prepared with FigTree version 1.4.3 [35] and edited with Microsoft Power Point (2016).

\subsection{Experiment to Produce Keratinases Using the Three Most Active Strains}

The three most active fungal strains were used in the submerged fermentation incubation, carried out as described for the preliminary submerged fermentation incubation above. Erlenmeyer flasks $(500 \mathrm{~mL})$ containing $100 \mathrm{~mL}$ of fermentation medium were used. After the fermentation period, the cell-free supernatants were subjected to $60 \%$ ammonium sulfate precipitation. The precipitated proteins were isolated and lyophilized using a freeze dryer (VirTis, model \#6KBTES-55, NY, USA). Lyophilized keratinases were dissolved separately in citrate buffer ( $\mathrm{pH}$ 5.0) and dialyzed twice at room temperature against the same buffer for $2 \mathrm{~h}$, removing the buffer every time. Then, they were stored overnight at $4{ }^{\circ} \mathrm{C}$ to exclude small molecules. The dialyzed keratinases were then lyophilized using a freeze dryer, weighed, and used as partially purified fungal keratinase enzymes to measure the activity of the enzymes and their optimal conditions.

\subsection{Effect of PH and Temperature on the Activity of Partially Purified Keratinases}

The partially purified fungal keratinases of the three selected fungi were used in the reaction mixture that contained $0.01 \mathrm{~g}$ keratinase and $0.01 \mathrm{~g}$ chicken keratin powder (each was prepared independently in a $50 \mathrm{mmol}$ citrate buffer solution of $1.0 \mathrm{~mL}$ ). The different experiments were prepared as three replicates and the absorbances were measured as above. Keratinase activity was calculated and expressed as kilo unit per g keratinase (KU g ${ }^{-1}$ keratinase).

Eight $\mathrm{pH}$ values (3.0-10.0) were tested. The buffers used were citrate buffer ( $\mathrm{pH} 3.0-6.0)$, phosphate buffer ( $\mathrm{pH} 7.0-8.0)$, and borate buffer ( $\mathrm{pH}$ 9.0-10.0). Then, six temperatures $\left(30-80{ }^{\circ} \mathrm{C}\right)$ at the optimum $\mathrm{pH}$ value of each microbial keratinase was tested. Divalent metal ions $\left(\mathrm{Ca}^{+2}, \mathrm{Co}^{+2}, \mathrm{Ni}^{+2}, \mathrm{Cu}^{+2}, \mathrm{Fe}^{+2}, \mathrm{Mg}^{+2}\right.$, and $\left.\mathrm{Zn}^{+2}\right)$ were tested by adding at the concentration of $5 \mathrm{mmol} \mathrm{mL}^{-1}$ as $\mathrm{CaCl}_{2}, \mathrm{CoCl}_{2}, \mathrm{NiCl}_{2}, \mathrm{CuSO}_{4}, \mathrm{FeSO}_{4}, \mathrm{MgSO}_{4}$, and $\mathrm{ZnSO}_{4}$. An enzyme inhibitor was tested using $5 \mathrm{mmol} \mathrm{mL}^{-1}$ ethylenediaminetetraacetic acid (EDTA). The activity of the microbial keratinase in the absence of metal ions or EDTA were measured under standard conditions to define $100 \%$ activity in optimal conditions.

\section{Results}

\subsection{Preliminary Experiment}

Six strains exhibited keratinase activity above $1500 \mathrm{IU} \mathrm{mL}^{-1} \mathrm{~min}^{-1}$ (Table 1). Fusarium brachygibbosum was the most active (3554 IU mL ${ }^{-1} \mathrm{~min}^{-1}$ ) followed by A. sydowii and Aspergillus stelliformis with the activities of 3336 and $3523 \mathrm{IU} \mathrm{mL}^{-1} \mathrm{~min}^{-1}$, respectively. Keratinase activity values from Aspergillus ustus, Alternaria alternata (AUMC 10932), and Chaetomium globosum showed 2091, 1681, and $1600 \mathrm{IU} \mathrm{mL} \mathrm{min}^{-1}$, respectively. The remaining tested fungi showed low keratinase activity ranging from 52 to $1398 \mathrm{IU} \mathrm{mL}^{-1} \mathrm{~min}^{-1}$. 


\subsection{Fungi Producing Active Microbial Keratinases}

The three most active fungal species were confirmed by by phylogenetic analysis as Aspergillus stelliformis, A. sydowii, and Fusarium brachygibbosum (Figure 1). The phylogenetic tree showed the relationship of our Aspergillus strains AUMC 10920 and AUMC 10935 to the other Aspergillus species. The Aspergillus species in this analysis showed $100 \%$ similarity to A. stelliformis CCF 5375 and A. sydowii CBS 593.65 (Figure 2). Sequencing data were submitted to GenBank and assigned accession numbers as MW045465 for A. stelliformis and MW045469 for $A$. sydowii. It is worth it to mention that $A$. stelliformis is a newly recorded species related to Aspergillus section Nidulantes that accommodates $A$. nidulans and other species developing biseriate conidiophores with light brown-pigmented stipes, and, if present, the ascomata embedded in masses of Hülle cells. The Fusarium strain AUMC 10937 was identified as F. brachygibbosum with GenBank accession number of MW045472 (Figure 3).
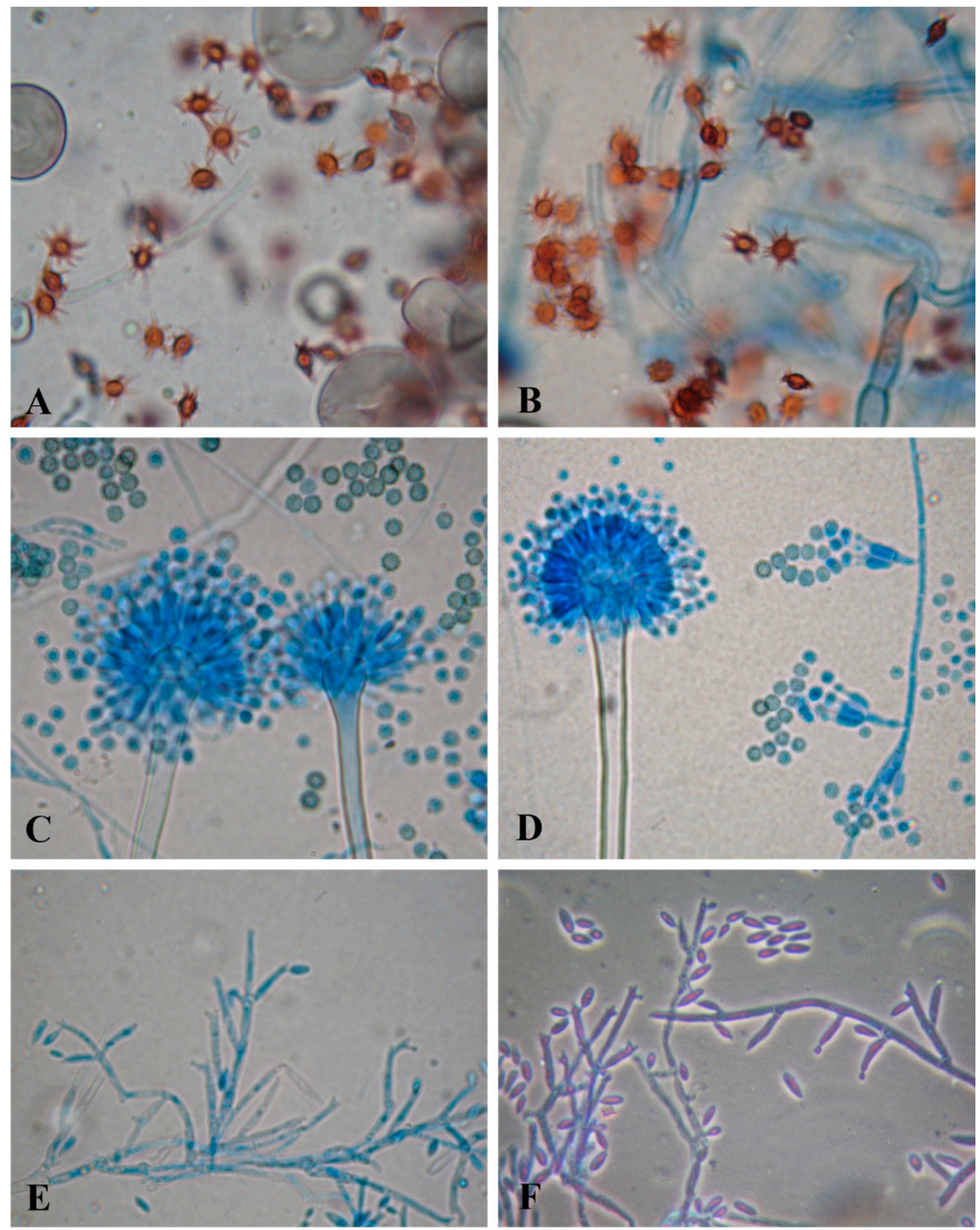

Figure 1. Light brown spores of A. stelliformis (A,B), biseriate conidiophores, and spinulose conidia of $A$. sydowii $(\mathbf{C}, \mathbf{D})$, and relatively curved and fusiform microconidia of $F$. brachygibbosum originated from mono and polyphialides $(\mathbf{E}, \mathbf{F})$. 


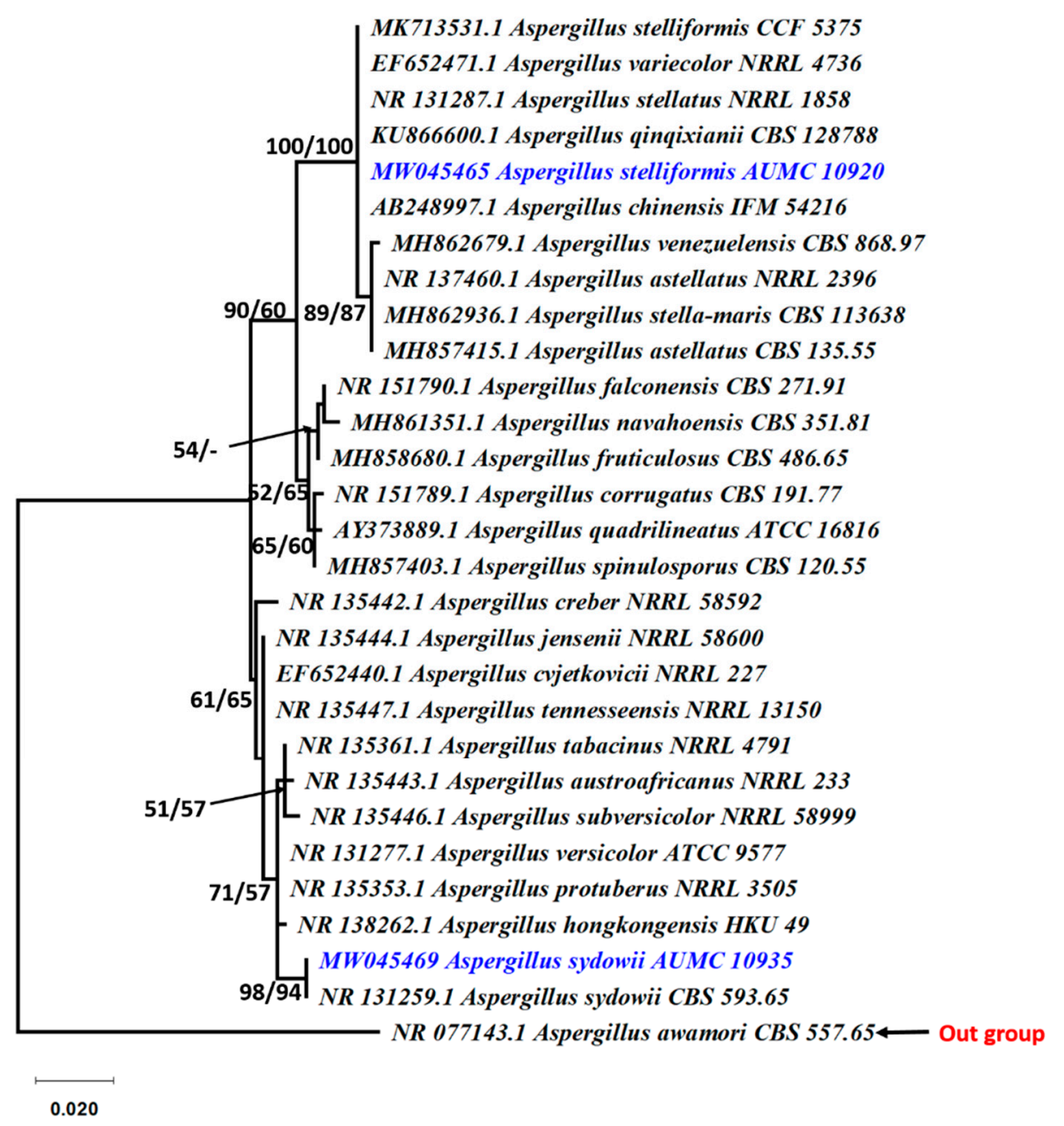

Figure 2. Phylogenetic tree generated from MP analysis based on ITS sequence data of Aspergillus stelliformis AUMC 10920 and A. sydowii AUMC 10935 associated to other related genes in Aspergillaceae. Blue color refers to the species in this study. Bootstrap support values (100 replications) for ML/MP combination equal to or greater than $50 \%$ are indicated at the respective nodes. The tree is rooted to Aspergillus awamori-CBS 557.65 as the out group.

\subsection{Yield and Activity of Keratinases}

In submerged fermentation, the three fungi produced keratinases with relatively high yield. It was possible to produce $4.0 \mathrm{~g}$ keratinase powder from A. stelliformis, $4.5 \mathrm{~g}$ from $A$. sydowii, and $3.7 \mathrm{~g}$ from F. brachygibbosum per liter of fermentation medium. The keratinases appeared to be active; the highest activity was reached at $\mathrm{pH} 8.0$ for each microbial keratinase, and were 105, 104, and $119 \mathrm{KU} / \mathrm{g}$ keratinase for A. stelliformis, A. sydowii, and F. brachygibbosum, respectively (Figure 4). The specific activities were 4223, 3522 , and $3277 \mathrm{IU} / \mathrm{mg}$ protein, respectively.

The optimum temperature was $50^{\circ} \mathrm{C}(\mathrm{pH}$ 8.0) for each of the three microbial keratinases. The activity values increased to 113,120 , and $130 \mathrm{KU} / \mathrm{g}$ keratinase produced by A. stelliformis, A. sydowii, and F. brachygibbosum, respectively (Figure 5). A notable observation was that $F$. brachygibbosum was active at a wide temperature range $\left(30-60^{\circ} \mathrm{C}\right)$. The optimum temperature $\left(50^{\circ} \mathrm{C}\right)$ also increased the specific activity of the three keratinases to 4521,4060 , and $3573 \mathrm{IU} / \mathrm{mg}$ protein for A. stelliformis, A. sydowii, and F. brachygibbosum, respectively. 


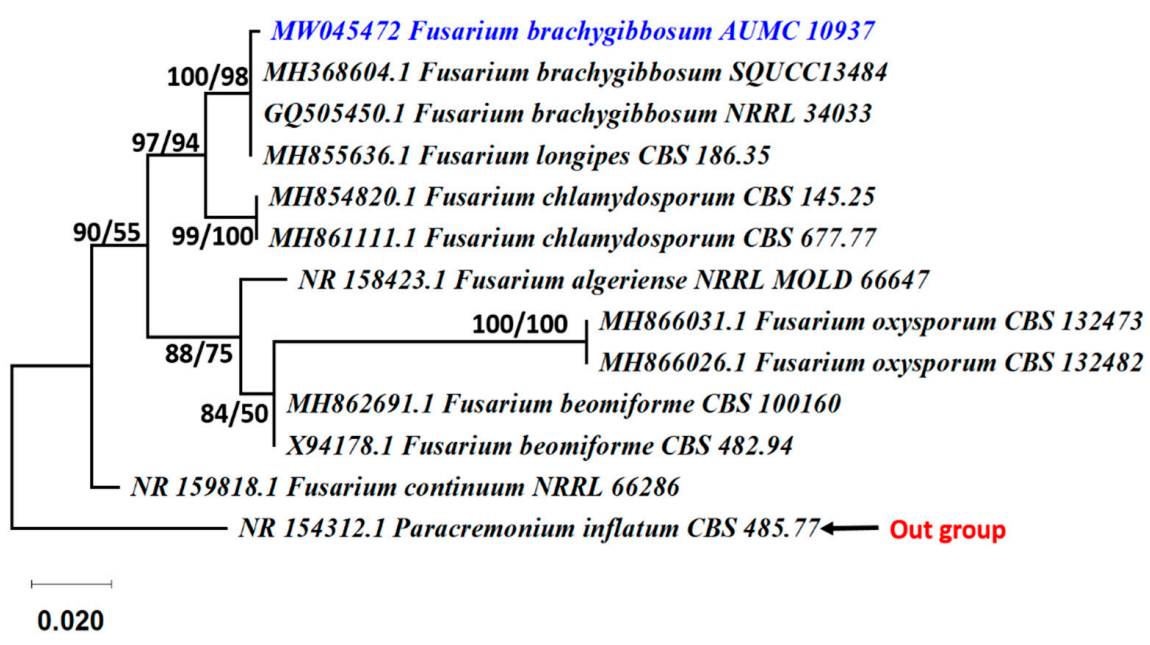

Figure 3. Phylogenetic tree generated from MP analysis based on ITS sequence data of F. brachygibbosum AUMC 10937 associated to other related genes in Nectriaceae. Blue color refers to the species in this study. Bootstrap support values (100 replications) for ML/MP combination equal to or greater than $50 \%$ are indicated at the respective nodes. The tree is rooted to Paracremonium inflatum CBS 485.77 as the out group.

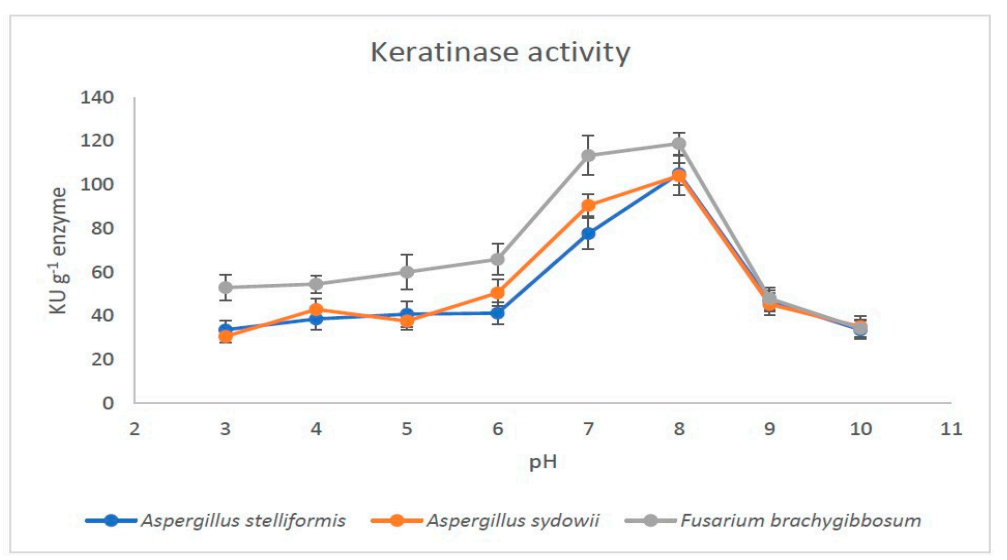

Figure 4. Effect of $\mathrm{pH}$ on the activity of fungal keratinases produced by A. stelliformis, A. sydowii, and F. brachygibbosum.

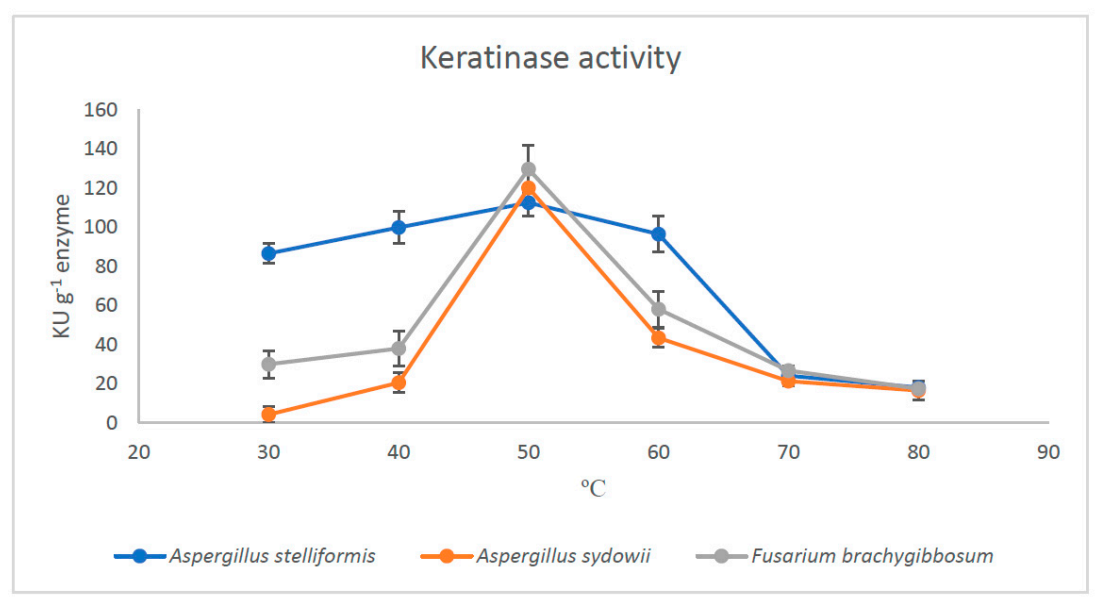

Figure 5. The Effect of temperature on the activity of keratinases produced by A. stelliformis, A. sydowii, and F. brachygibbosum. 
EDTA and the metal ions had strong inhibitory effects on the activity of the keratinases produced when tested under the optimum conditions observed ( $\mathrm{pH} 8$ and $50{ }^{\circ} \mathrm{C}$ ). The maximum inhibitory effect was with EDTA in case of the keratinases produced by A. stelliformis and A. sydowii, but not by F. brachygibbosum (Table 2). For F. brachygibbosum, the inhibitory metal ions were $\mathrm{Ca}, \mathrm{Cu}$, and $\mathrm{Zn}$.

Table 2. Effect of metal ions and EDTA $\left(5 \mathrm{mmol} \mathrm{mL}{ }^{-1}\right)$ on keratinase activity produced by different fungi (mean $\pm S D, n=3$ ). The results are expressed as the proportion of the activity in the tested inhibitory conditions, from the keratinase activity in the control without inhibitors.

\begin{tabular}{cccc}
\hline $\begin{array}{c}\text { Control Activity } \\
\mathbf{K U g}^{-\mathbf{1}} \text { Enzyme }\end{array}$ & $\mathbf{1 1 3}$ & $\mathbf{1 2 1}$ & $\mathbf{1 3 0}$ \\
\hline Inhibitor & A. stelliformis & A. sydowii & F. brachygibbosum \\
\hline $\mathrm{FeSO}_{4}$ & $28 \pm 4$ & $27 \pm 2$ & $24 \pm 3$ \\
$\mathrm{ZnSO}_{4}$ & $29 \pm 3$ & $18 \pm 2$ & $23 \pm 4$ \\
$\mathrm{CaCl}_{2}$ & $34 \pm 6$ & $22 \pm 6$ & $22 \pm 4$ \\
$\mathrm{CuSO}_{4}$ & $28 \pm 3$ & $22 \pm 5$ & $23 \pm 2$ \\
$\mathrm{NiCl}_{2}$ & $30 \pm 4$ & $58 \pm 9$ & $45 \pm 4$ \\
$\mathrm{CoCl}_{2}$ & $76 \pm 8$ & $33 \pm 8$ & $27 \pm 4$ \\
$\mathrm{MgSO}_{4}$ & $27 \pm 5$ & $17 \pm 5$ & $53 \pm 8$ \\
EDTA & $7 \pm 1$ & $17 \pm 4$ & $52 \pm 6$ \\
\hline
\end{tabular}

\section{Discussion}

Microbial keratinases are considered highly useful in many biotechnological applications. For instance, they are known as plant growth promoters [36]. A more recent application involves treating keratinous waste produced in agriculture and leather industries. This waste is difficult to treat with proteases, such as papain, pepsin, and trypsin [30]. Finding efficient degraders of keratin offers possibilities to treat waste from cattle, poultry, and leather industries, and keratinases has been studied with the aim to degrade the different waste material $[37,38]$. The advantages of using natural keratinophilic microbes in producing enzymes are the low cost and that the byproducts are nontoxic (and can even be utilized elsewhere) [39]. Byproducts, such as amino acids, polypeptides, vitamins, and detergent additives are promising novel applications that improve the sustainability of agriculture [40,41]. The mechanisms behind the degradation of keratinous materials still requires further studies. The process of keratinolysis can be catalyzed by a single keratinase, or more efficiently, in synergy with other enzymes [7]. Other enzymes such as disulfide reductases catalyze the breakage of disulfide bonds. Metabolic cooperation with amino acid metabolism, urea cycle, and disulfide reduction was revealed using metagenomic analysis [42]. Different reducing agents, such as $\beta$-mercaptoethanol and dithiothreitol were present when keratinases produced by fungi and actinomycetes. Thermoactinomyces sp., Trichophyton sp., Streptomyces sp., A. parasiticus and A. niger were compared in a review of Peng et al. [43]. The mechanism behind the keratin degradation has been studied with keratinases produced by Bacillus thuringiensis isolated from donkey hairs. Scanning electron microscopy and Fourier transform infrared spectrophotometry showed the disintegration and disruption of the disulphide bonds of the keratin structure [44]. The use of natural microbes reduces the costs of the enzyme production and, at the same time, offers economic processes to waste management [2]. Each of the three species studied appeared to be good candidates to produce active keratinases. Different species of Aspergillus have been reported often as potential producers of keratinases the optimum conditions varying a lot. The optimum conditions for Aspergillus terreus in a 25-days incubation were $40{ }^{\circ} \mathrm{C}$ and $\mathrm{pH} 8$ [45]. The mutants of 28 strains of $A$. niger produced varying amounts of keratinases on solid state fermentation in basal medium containing chicken feathers after $7 \mathrm{~d}$; the highest activity of keratinases was achieved at $\mathrm{pH} 5$ [46]. When cultivated in feather meal basal medium containing $2 \%(w / v)$ chicken feather for 16 days, the 
optimum of A. flavus was at $\mathrm{pH} 8$ and $28^{\circ} \mathrm{C}$ [47]. Aspergillus sp. DHE7 recovered from poultry farm soil in Egypt had the maximum keratinase activity $199 \mathrm{IU} / \mathrm{mL}$ in a $2 \%$ chicken feather substrate when incubated for 4 days at $30{ }^{\circ} \mathrm{C}$ and $\mathrm{pH} 6.0$ [48]. The addition of $0.5 \%$ sucrose as a supportive carbon source raised the keratinase activity to $226 \mathrm{IU} / \mathrm{mL}$. The best substrates for the keratinase activity were goat hair $(452 \mathrm{IU} / \mathrm{mL})$, turkey feathers (435 IU/mL) and sheep wool (322 IU/mL). Our Aspergillus species had a clearly higher temperature optimum, $50{ }^{\circ} \mathrm{C}$.

In addition to Aspergillus, several other fungal genera have been shown to produce active keratinases as well. Scopulariopsis brevicaulis keratinolytic activity was the highest on chicken feathers followed by human nails and human hair [49]. Cochliobolus hawaiiensis achieved the maximum development of alkaline keratinase after an incubation for $15 \mathrm{~d}$ at $30^{\circ} \mathrm{C}$ and $\mathrm{pH} 9.5$ [50]. Chrysosporium tropicum optimum production of keratinase in medium containing chicken feathers was after $21 \mathrm{~d}$ at $25^{\circ} \mathrm{C}$ using $1 \%$ glucose as carbon source [39]. Trichophyton ajelloi had its maximum enzyme activity $(6.3 \mathrm{KU} / \mathrm{mL})$ at $30^{\circ} \mathrm{C}$ [51]. Keratinolytic activity of Chrysosporium tropicum was the highest $(8.6 \mathrm{KU} / \mathrm{mL})$ on the 40 th day of the incubation [40]. For Microsporum gypseum $(78 \mathrm{KU} / \mathrm{mL})$ and M. canis $(76 \mathrm{KU} / \mathrm{mL})$ the highest activity was recorded on the 20th day of the incubation [41]. Bacillus thuringiensis showed the activity of $422 \mathrm{U} / \mathrm{mL}$ at $50{ }^{\circ} \mathrm{C}$ and $\mathrm{pH} 9$ [44]. In general, it is difficult to compare the values of enzyme activity between different studies due to slight differences in methodology. Therefore, the comparisons should be done with caution.

Many studies have confirmed the dependence of microbial keratinase activity from metals [52,53]. This was the case with our three species A. sydowii, A. stelliformis and F. brachygibbosum as well. We found no previous information about our species but a featherdegrading culture of Aspergillus oryzae was activated by $\mathrm{Ca}$ and Ba ions while inhibited by EDTA and $\mathrm{Pb}$ ions [54]. Under solid state fermentation with chicken feathers, A. flavipes keratinase activity was greatly inhibited by EDTA, $\mathrm{Hg}^{2+}, \mathrm{Fe}^{3+}$ [55]. No great effect on A. flavipes keratinase was observed due to the presence of $\mathrm{Zn}^{2+}, \mathrm{Mg}^{2+}$ and $\mathrm{Cu}^{2+}$. The published research reveals that different fungal species have highly variable optimum conditions. This indicates that the optimum culturing conditions and the inhibitory compounds must be examined for each species separately.

Many of the Fusarium species are known as opportunistic pathogens causing many plant diseases, among them is one of the most destructive plant diseases Fusarium wilt of banana [56]. Fusarium brachygibbosum specifically has caused, for instance, leaf spot disease of date palms and dry rot disease of citrus trees [57,58]. It was reported as a causative agent of date palm wilting disease although its pathogenicity was assessed as low [59]. Fusarium species are known as toxigenic fungi secreting mycotoxins in food and feed such as cereals [60,61]. Although F. brachygibbosum keratinase was the most active in a wide temperature range tested in our study, it must be recommended with caution because of its known pathogenicity to plants.

Aspergillus sydowii is not known as especially pathogenic but its role as an opportunistic pathogen causing diseases for instance in coral reefs has been studied in several seas [62,63]. Aspergillus sydowii is known as a species tolerating highly saline conditions and reported to have potential to be used in different biotechnological solutions. Several Aspergillus species in general are known to have adverse health effects on humans [64]. Most often, the fungi have been reported to cause local infections and allergy [65]. However, we found no reports about severe health effects of either of our Aspergillus species. Its potential has been verified for instance, in the remediation of polyaromatic hydrocarbons, pesticides, and pharmaceutical compounds [66,67]. Aspergillus sydowii was observed to adsorb heavy metals (Cd) and degrade pesticides (trichlorfon) in vitro [68]. In addition, A. sydowii, as a producer of anthocyanins, has many potential applications in human health and for instance as natural dyes of foodstuff [69].

Aspergillus sydowiii has been shown to produce many different enzymes that have potential in many biotechnological applications. Cellulase was produced under submerged fermentation [70] and xylanases under solid-state fermentation [71]. Moreover, 
tannases [72] and lignocellulosic enzymes offer possibilities to food and bioenergy applications [73]. We can add keratinases the list of $A$. sydowiii for the first time.

Only some information about $A$. stelliformis was found [74]. No indication about its bioactivities nor mentions about its potential use in biotechnology were found. We report, for the first time, the potential of $A$. stelliformis to produce keratinases and its potential to be used in applications to degrade keratinous material.

\section{Conclusions}

Aspergillus stelliformis, A. sydowii, and F. brachygibbosum appeared to produce keratinases that had high activity. F. brachygibbosum keratinase was the most active in a wide temperature range. However, as a producer of keratinases, it must be used with caution and cannot be recommended because of its known phytopathogenicity. Aspergillus sydowii is known as a species with several potential biotechnological solutions. To this long list published using A. sydowii, we can add the production of the active keratinase enzyme. We also introduce a new-recorded species, $A$. stelliformis, to be used in biotechnological solutions as a producer of active microbial keratinase. Although further studies are required, both Aspergillus species could be used in degrading problematic and recalcitrant keratinous waste and in developing sustainable agriculture.

Author Contributions: S.S.A.: Collection and outline the study, F.A.: Analysis, writing, revising, H.A.G.; data analysis; H.S.: editing; S.A.: Revising, A.M.M.: Molecular work and writing, O.A.A.-B.: Writing and Revising. All authors contributed to data analysis, drafting, or revising the manuscript. All authors have read and agreed to the published version of the manuscript.

Funding: This research was funded by the Deanship of Scientific Research at Princess Nourah bint Abdulrahman University through the Fast-track Research Funding Program to support publication in the top journal (Grant no. 42-FTTJ-65).

Institutional Review Board Statement: Not applicable.

Informed Consent Statement: Not applicable.

Data Availability Statement: All data related to this manuscript is incorporated in the manuscript only.

Conflicts of Interest: The authors declare that there are no potential conflict of interest regarding the publication of this paper.

\section{References}

1. Sharma, S.; Gupta, A. Sustainable management of keratin waste biomass: Applications and future perspectives. Brazilian Arch. Biol. Technol. 2016, 59. [CrossRef]

2. Verma, A.; Singh, H.; Anwar, S.; Chattopadhyay, A.; Tiwari, K.K.; Kaur, S.; Dhilon, G.S. Microbial keratinases: Industrial enzymes with waste management potential. Crit. Rev. Biotechnol. 2017, 37, 476-491. [CrossRef]

3. Reddy, C.C.; Khilji, I.A.; Gupta, A.; Bhuyar, P.; Mahmood, S.; AL-Japairai, K.A.S.; Chua, G.K. Valorization of keratin waste biomass and its potential applications. J. Water Process Eng. 2021, 40, 101707. [CrossRef]

4. Hassan, M.A.; Abol-Fotouh, D.; Omer, A.M.; Tamer, T.M.; Abbas, E. Comprehensive insights into microbial keratinases and their implication in various biotechnological and industrial sectors: A review. Int. J. Biol. Macromol. 2020, 154, 567-583. [CrossRef]

5. Gafar, A.; Khayat, M.E.; Ahmad, S.A.; Yasid, N.A.; Shukor, M.Y. Response Surface Methodology for the Optimization of Keratinase Production in Culture Medium Containing Feathers by Bacillus sp. UPM-AAG1. Catalysts 2020, 10, 848. [CrossRef]

6. Bohacz, J.; Korniłłowicz-Kowalska, T.; Kitowski, I.; Ciesielska, A. Degradation of chicken feathers by Aphanoascus keratinophilus and Chrysosporium tropicum strains from pellets of predatory birds and its practical aspect. Int. Biodeterior. Biodegrad. 2020, 151, 104968. [CrossRef]

7. Nnolim, N.E.; Udenigwe, C.C.; Okoh, A.I.; Nwodo, U.U. Microbial Keratinase: Next Generation Green Catalyst and Prospective Applications. Front. Microbiol. 2020, 11, 3280. [CrossRef] [PubMed]

8. Günyar, O.A.; Kiraç, S.; Aldi, B.; Ergin, C. Isolation and identification of keratinophilic fungi in soil samples from excavation area of ancient city of Stratonikeia, Turkey and determination of its enzyme potentials. J. Environ. Biol. 2020, 41, 1521-1525. [CrossRef]

9. Fang, Z.; Zhang, J.; Liu, B.; Du, G.; Chen, J. Biodegradation of wool waste and keratinase production in scale-up fermenter with different strategies by Stenotrophomonas maltophilia BBE11-1. Bioresour. Technol. 2013, 140, 286-291. [CrossRef]

10. Akhter, M.; Wal Marzan, L.; Akter, Y.; Shimizu, K. Microbial bioremediation of feather waste for keratinase production: An outstanding solution for leather dehairing in tanneries. Microbiol. Insights 2020, 13, 1178636120913280. [CrossRef] [PubMed] 
11. Akram, F.; ul Haq, I.; Jabbar, Z. Production and characterization of a novel thermo-and detergent stable keratinase from Bacillus sp. NKSP-7 with perceptible applications in leather processing and laundry industries. Int. J. Biol. Macromol. 2020, 164, 371-383. [CrossRef]

12. Avdiyuk, K.V.; Varbanets, L.D. Keratinolytic enzymes: Producers, physical and chemical properties. Application for biotechnology. Biotechnol. Acta 2019, 12, 27-45.

13. Abdel-Fattah, A.M.; El-Gamal, M.S.; Ismail, S.A.; Emran, M.A.; Hashem, A.M. Biodegradation of feather waste by keratinase produced from newly isolated Bacillus licheniformis ALW1. J. Genet. Eng. Biotechnol. 2018, 16, 311-318. [CrossRef] [PubMed]

14. Brandelli, A.; Daroit, D.J.; Riffel, A. Biochemical features of microbial keratinases and their production and applications. Appl. Microbiol. Biotechnol. 2010, 85, 1735-1750. [CrossRef]

15. Moridshahi, R.; Bahreini, M.; Sharifmoghaddam, M.; Asoodeh, A. Biochemical characterization of an alkaline surfactant-stable keratinase from a new keratinase producer, Bacillus zhangzhouensis. Extremophiles 2020, 24, 693-704. [CrossRef]

16. Vidmar, B.; Vodovnik, M. Microbial keratinases: Enzymes with promising biotechnological applications. Food Technol. Biotechnol. 2018, 56, 312-328. [CrossRef] [PubMed]

17. Köhler, J.R.; Casadevall, A.; Perfect, J. The spectrum of fungi that infects humans. Cold Spring Harb. Perspect. Med. 2015, 5, a019273. [CrossRef] [PubMed]

18. Abirami, S.; Ragavi, R.; Antony, V.S. Utilization of keratinolytic Lichtheimia corymbifera AS1 for degradation of cattle hoove-A slaughter house waste to use in plant growth. Biointerface Res. Appl. Chem 2020, 10, 6417-6426.

19. Sousa, M.; Souza, O.; Maciel, M.; Cruz, R.; Rêgo, M.G.; Magalhães, O.; Pessoa-Júnior, A.; Porto, A.; Souza-Motta, C. Keratinolytic potential of fungi isolated from soil preserved at the Micoteca URM. Eur. J. Biotechnol. Biosci. 2015, 3, 10-15.

20. Paul, T.; Das, A.; Mandal, A.; Halder, S.K.; DasMohapatra, P.K.; Pati, B.R.; Mondal, K.C. Production and purification of keratinase using chicken feather bioconversion by a newly isolated Aspergillus fumigatus TKF1: Detection of valuable metabolites. Biomass Convers. Biorefinery 2014, 4, 137-148. [CrossRef]

21. Bagewadi, Z.K.; Mulla, S.I.; Ninnekar, H.Z. Response surface methodology based optimization of keratinase production from Trichoderma harzianum isolate HZN12 using chicken feather waste and its application in dehairing of hide. J. Environ. Chem. Eng. 2018, 6, 4828-4839. [CrossRef]

22. Gradišar, H.; Friedrich, J.; Križaj, I.; Jerala, R. Similarities and specificities of fungal keratinolytic proteases: Comparison of keratinases of Paecilomyces marquandii and Doratomyces microsporus to some known proteases. Appl. Environ. Microbiol. 2005, 71, 3420-3426. [CrossRef] [PubMed]

23. Alwakeel, S.S. Characterization of keratinophilic fungal species and other non-dermatophytes in hair and nail samples in riyadh, Saudi Arabia. Ass. Univ. Bull. Environ. Res. 2018, 21, 3-22. [CrossRef]

24. Łaba, W.; Szczekala, K.B. Keratinolytic proteases in biodegradation of pretreated feathers. Polish J. Environ. Stud. 2013, 22, 1101-1109.

25. Lowry, O.H.; Rosebrough, N.J.; Farr, A.L.; Randall, R.J. Protein measurement with the Folin phenol reagent. J. Biol. Chem. 1951, 193, 265-275. [CrossRef]

26. Moubasher, A.H.; Ismail, M.; Mohamed, R.; Al-Bedak, O. Production and purification of extreme xylanase from Aspergillus flavus AUMC 10331 in sub-merged fermentation. Eur. J. Biol. Res. 2019, 9, 20-28.

27. Al-Bedak, O.A.; Moubasher, A.H. Aspergillus gaarensis, a new addition to section Circumdati from soil of Lake El-Gaar in Wadi-El-Natron, Egypt. Stud. Fungi 2020, 5, 59-65. [CrossRef]

28. Ameen, F.; Moslem, M.; Hadi, S.; Al-Sabri, A.E. Biodegradation of diesel fuel hydrocarbons by mangrove fungi from Red Sea Coast of Saudi Arabia. Saudi J. Biol. Sci. 2016, 23. [CrossRef]

29. El-Fakharany, E.M.; Hassan, M.A.; Taha, T.H. Production and application of extracellular laccase produced by Fusarium oxysporum EMT. Int. J. Agric. Biol. 2016, 18, 939-947. [CrossRef]

30. Katoh, K.; Standley, D.M. MAFFT multiple sequence alignment software version 7: Improvements in performance and usability. Mol. Biol. Evol. 2013, 30, 772-780. [CrossRef]

31. Criscuolo, A.; Gribaldo, S. BMGE (Block Mapping and Gathering with Entropy): A new software for selection of phylogenetic informative regions from multiple sequence alignments. BMC Evol. Biol. 2010, 10, 1-21. [CrossRef]

32. Guindon, S.; Dufayard, J.-F.; Lefort, V.; Anisimova, M.; Hordijk, W.; Gascuel, O. New algorithms and methods to estimate maximum-likelihood phylogenies: Assessing the performance of PhyML 3.0. Syst. Biol. 2010, 59, 307-321. [CrossRef]

33. Felsenstein, J. Confidence limits on phylogenies: An approach using the bootstrap. Evolution 1985, 39, 783-791.

34. Lefort, V.; Longueville, J.-E.; Gascuel, O. SMS: Smart model selection in PhyML. Mol. Biol. Evol. 2017, 34, 2422-2424. [CrossRef] [PubMed]

35. Rambaut, A.; Drummond, A.J. FigTree, version 1.4.0.; University of Edinburgh: Edinburgh, UK, 2012.

36. Kothari, D.; Rani, A.; Goyal, A. Keratinases. In Current Developments in Biotechnology and Bioengineering; Elsevier: Amsterdam, The Netherlands, 2017; pp. 447-469.

37. Kang, D.; Herschend, J.; Al-Soud, W.A.; Mortensen, M.S.; Gonzalo, M.; Jacquiod, S.; Sørensen, S.J. Enrichment and characterization of an environmental microbial consortium displaying efficient keratinolytic activity. Bioresour. Technol. 2018, 270, 303-310. [CrossRef]

38. Kalaikumari, S.S.; Vennila, T.; Monika, V.; Chandraraj, K.; Gunasekaran, P.; Rajendhran, J. Bioutilization of poultry feather for keratinase production and its application in leather industry. J. Clean. Prod. 2019, 208, 44-53. [CrossRef] 
39. Menon, S.; Savur, B.; Kasat, D.; Mavani, U.; Singh, S.; Rane, M. Management and utilization of Keratin Waste-A review. Int. J. Adv. Res. Ideas Innov. Technol. 2020, 6, 511-515.

40. Reddy, M.R.; Reddy, K.S.; Chouhan, Y.R.; Bee, H.; Reddy, G. Effective feather degradation and keratinase production by Bacillus pumilus GRK for its application as bio-detergent additive. Bioresour. Technol. 2017, 243, 254-263. [CrossRef]

41. Peng, Z.; Mao, X.; Zhang, J.; Du, G.; Chen, J. Biotransformation of keratin waste to amino acids and active peptides based on cell-free catalysis. Biotechnol. Biofuels 2020, 13, 1-12. [CrossRef] [PubMed]

42. Kang, D.; Huang, Y.; Nesme, J.; Herschend, J.; Jacquiod, S.; Kot, W.; Hansen, L.H.; Lange, L.; Sørensen, S.J. Metagenomic analysis of a keratin-degrading bacterial consortium provides insight into the keratinolytic mechanisms. Sci. Total Environ. 2021, 761, 143281. [CrossRef]

43. Peng, Z.; Zhang, J.; Du, G.; Chen, J. Keratin waste recycling based on microbial degradation: Mechanisms and prospects. ACS Sustain. Chem. Eng. 2019, 7, 9727-9736. [CrossRef]

44. Hassan, M.A.; Taha, T.H.; Hamad, G.M.; Hashem, M.; Alamri, S.; Mostafa, Y.S. Biochemical characterisation and application of keratinase from Bacillus thuringiensis MT1 to enable valorisation of hair wastes through biosynthesis of vitamin B-complex. Int. J. Biol. Macromol. 2020, 153, 561-572. [CrossRef]

45. Koutb, M.; Morsy, F.M.; Bagy, M.M.K.; Hassan, E.A. Optimization of extracellular keratinase production by Aspergillus terreus isolated from chicken's litter. J. Adv. Lab. Res. Biol. 2012, 3, 210-216.

46. Mazotto, A.M.; Couri, S.; Damaso, M.C.T.; Vermelho, A.B. Degradation of feather waste by Aspergillus niger keratinases: Comparison of submerged and solid-state fermentation. Int. Biodeterior. Biodegrad. 2013, 85, 189-195. [CrossRef]

47. Kim, J.-D. Purification and characterization of a keratinase from a feather-degrading fungus, Aspergillus flavus Strain K-03. Mycobiology 2007, 35, 219-225. [CrossRef]

48. El-Ghonemy, D.H.; Ali, T.H. Optimization of physico-chemical parameters for hyper keratinase production from a newly isolated Aspergillus sp. DHE7 using chicken feather as substrate-management of biowaste. J. Appl. Pharm. Sci 2017, 7, 171-178.

49. Sharaf, E.F.; Khalil, N.M. Keratinolytic activity of purified alkaline keratinase produced by Scopulariopsis brevicaulis (Sacc.) and its amino acids profile. Saudi J. Biol. Sci. 2011, 18, 117-121. [CrossRef] [PubMed]

50. Isaac, G.S.; Abu-Tahon, M.A. Dehairing capability of alkaline keratinase produced by new isolated Cochliobolus hawaiiensis AUMC 8606 grown on chicken feather. Rom. Biotechnol. Lett. 2016, 22, 12147-12154.

51. Kačinová, V.; Kolčáková, V.; Petranová, D. Axiocentric media education as a strategy for the cultivation of media recipients. Eur. J. Sci. Theol. 2014, 10, 103-116.

52. Tapia, D.M.T.; Simões, M.L.G. Production and partial characterization of keratinase produced by a microorganism isolated from poultry processing plant wastewater. African J. Biotechnol. 2008, 7, 296-300.

53. Riffel, A.; Brandelli, A.; Bellato, C.d.M.; Souza, G.H.M.F.; Eberlin, M.N.; Tavares, F.C.A. Purification and characterization of a keratinolytic metalloprotease from Chryseobacterium sp. kr6. J. Biotechnol. 2007, 128, 693-703. [CrossRef]

54. Farag, A.M.; Hassan, M.A. Purification, characterization and immobilization of a keratinase from Aspergillus oryzae. Enzyme Microb. Technol. 2004, 34, 85-93. [CrossRef]

55. El-Ayouty, Y.M.; El-Said, A.; Salama, A.M. Purification and characterization of a keratinase from the feather-degrading cultures of Aspergillus flavipes. Afr. J. Biotechnol. 2012, 11, 2313-2319. [CrossRef]

56. Ploetz, R.C. Fusarium wilt of banana. Phytopathology 2015, 105, 1512-1521. [CrossRef] [PubMed]

57. Al Nadabi, W.; Faisal, M.; Mohammed, M.A. Patient safety culture in Oman: A national study. J. Eval. Clin. Pract. 2020, 26, 1406-1415. [CrossRef] [PubMed]

58. Ezrari, S.; Lahlali, R.; Radouane, N.; Tahiri, A.; Asfers, A.; Boughalleb-M'Hamdi, N.; Amiri, S.; Lazraq, A. Characterization of Fusarium species causing dry root rot disease of citrus trees in Morocco. J. Plant Dis. Prot. 2020, 128, 1-17.

59. Nishad, R.; Ahmed, T.A. Survey and identification of date palm pathogens and indigenous biocontrol agents. Plant Dis. 2020, 104, 2498-2508. [CrossRef] [PubMed]

60. Escrivá, L.; Font, G.; Manyes, L. In vivo toxicity studies of Fusarium mycotoxins in the last decade: A review. Food Chem. Toxicol. 2015, 78, 185-206. [CrossRef]

61. Gutleb, A.C.; Morrison, E.; Murk, A.J. Cytotoxicity assays for mycotoxins produced by Fusarium strains: A review. Environ. Toxicol. Pharmacol. 2002, 11, 309-320. [CrossRef]

62. Ein-Gil, N.; Ilan, M.; Carmeli, S.; Smith, G.W.; Pawlik, J.R.; Yarden, O. Presence of Aspergillus sydowii, a pathogen of gorgonian sea fans in the marine sponge Spongia obscura. ISME J. 2009, 3, 752-755. [CrossRef] [PubMed]

63. Soler-Hurtado, M.M.; Sandoval-Sierra, J.V.; Machordom, A.; Diéguez-Uribeondo, J. Aspergillus sydowii and other potential fungal pathogens in gorgonian octocorals of the Ecuadorian Pacific. PLoS One 2016, 11, e0165992. [CrossRef]

64. Mousavi, B.; Hedayati, M.T.; Hedayati, N.; Ilkit, M.; Syedmousavi, S. Aspergillus species in indoor environments and their possible occupational and public health hazards. Curr. Med. Mycol. 2016, 2, 36. [CrossRef]

65. Sabino, R.; Verissimo, C.; Viegas, C.; Viegas, S.; Brandão, J.; Alves-Correia, M.; Borrego, L.-M.; Clemons, K.V.; Stevens, D.A.; Richardson, M. The role of occupational Aspergillus exposure in the development of diseases. Med. Mycol. 2019, 57, S196-S205. [CrossRef]

66. Peidro-Guzmán, H.; Pérez-Llano, Y.; González-Abradelo, D.; Fernández-López, M.G.; Dávila-Ramos, S.; Aranda, E.; Hernández, D.R.O.; Garcia, A.O.; Lira-Ruan, V.; Pliego, O.R.; et al. Transcriptomic analysis of polyaromatic hydrocarbon degradation by the halophilic fungus Aspergillus sydowii at hypersaline conditions. Environ. Microbiol. 2020. [CrossRef] 
67. González-Abradelo, D.; Pérez-Llano, Y.; Peidro-Guzmán, H.; del Rayo Sánchez-Carbente, M.; Folch-Mallol, J.L.; Aranda, E.; Vaidyanathan, V.K.; Cabana, H.; Gunde-Cimerman, N.; Batista-García, R.A. First demonstration that ascomycetous halophilic fungi (Aspergillus sydowii and Aspergillus destruens) are useful in xenobiotic mycoremediation under high salinity conditions. Bioresour. Technol. 2019, 279, 287-296. [CrossRef]

68. Zhang, C.; Tao, Y.; Li, S.; Tian, J.; Ke, T.; Wei, S.; Wang, P.; Chen, L. Simultaneous degradation of trichlorfon and removal of Cd (II) by Aspergillus sydowii strain PA F-2. Environ. Sci. Pollut. Res. 2019, 26, 26844-26854. [CrossRef] [PubMed]

69. Bu, C.; Zhang, Q.; Zeng, J.; Cao, X.; Hao, Z.; Qiao, D.; Cao, Y.; Xu, H. Identification of a novel anthocyanin synthesis pathway in the fungus Aspergillus sydowii H-1. BMC Genomics 2020, 21, 1-16. [CrossRef] [PubMed]

70. Matkar, K.; Chapla, D.; Divecha, J.; Nighojkar, A.; Madamwar, D. Production of cellulase by a newly isolated strain of Aspergillus sydowii and its optimization under submerged fermentation. Int. Biodeterior. Biodegrad. 2013, 78, 24-33. [CrossRef]

71. Nair, S.G.; Sindhu, R.; Shashidhar, S. Purification and biochemical characterization of two xylanases from Aspergillus sydowii SBS 45. Appl. Biochem. Biotechnol. 2008, 149, 229-243. [CrossRef] [PubMed]

72. Albuquerque, K.K.; Albuquerque, W.W.; Costa, R.M.; Batista, J.M.S.; Marques, D.A.; Bezerra, R.P.; Herculano, P.N.; Porto, A.L. Biotechnological potential of a novel tannase-acyl hydrolase from Aspergillus sydowii using waste coir residue: Aqueous two-phase system and chromatographic techniques. Biocatal. Agric. Biotechnol. 2020, 23, 101453. [CrossRef]

73. Cong, B.; Wang, N.; Liu, S.; Liu, F.; Yin, X.; Shen, J. Isolation, characterization and transcriptome analysis of a novel Antarctic Aspergillus sydowii strain MS-19 as a potential lignocellulosic enzyme source. BMC Microbiol. 2017, 17, 1-14. [CrossRef] [PubMed]

74. Sklenávr, F.; Jurjević, Ž.; Peterson, S.W.; Kolavr'ik, M.; Nováková, A.; Flieger, M.; Stoduulková, E.; Kubátová, A.; Hubka, V. Increasing the species diversity in the Aspergillus section Nidulantes: Six novel species mainly from the indoor environment. Mycologia 2020, 112, 342-370. [CrossRef] [PubMed] 